\title{
A green, solvent-free route to functionalised metal-organic frameworks with UiO-66 topology
}

Received 00th January 20xx, Accepted 00th January 20xx

DOI: $10.1039 / \times 0 \times x 00000 x$

www.rsc.org/

\author{
Roberto D'Amato, ${ }^{a}$ Fabio Marmottini, ${ }^{a}$ Matthew J. McPherson, ${ }^{\mathrm{b}}$ Marco Taddei ${ }^{*, \mathrm{~b}}$ and Ferdinando \\ Costantino*,a
}

We report a solvent-free procedure for the high-yield synthesis of metal-organic frameworks of UiO-66 topology starting from a range of commercial $\mathrm{Zr}(\mathrm{IV})$ precursors and various substituted dicarboxylic linkers. The syntheses are carried out by simply grinding the reagents in the presence of a small volume of acetic acid as modulator, followed by incubation at either room temperature or $120^{\circ} \mathrm{C}$. Use of a ball mill for the grinding step is demonstrated to enable facile scale up of the synthesis. High acidity of the linker is found to be a crucial factor in affording materials of quality comparable to that of products obtained in solvo- or hydrothermal conditions.

The development of green and scalable procedures for the synthesis of metal-organic frameworks (MOFs) is currently considered the main factor to enable widespread industrial application and commercialization of these materials. ${ }^{1,2}$ Scientific attention is mainly focussed on the production of highly stable MOF sat low cost, in high yield and fulfilling the requirements of sustainability and green chemistry principles. ${ }^{3,4}$ Zirconium-based MOFs (Zr-MOFs) are currently considered benchmark materials for their high chemical and thermal stability, structural versatility and employment in a vast range of applications, ranging from gas separation, ${ }^{5-7}$ catalysis, ${ }^{8,9}$ water sorption, ${ }^{10,11}$ proton conductivity ${ }^{12}$ and drug delivery. ${ }^{13}$ Their structure is based on the different connectivity of hexanuclear clusters of formula $\mathrm{Zr}_{6} \mathrm{O}_{6}(\mathrm{OH})_{4}{ }^{12+}$ with polytopic carboxylic linkers, designing MOFs with variable degrees of connectivity and topologies, such as fcu (UiO-66 and MOF-801), csq (NU-1000) and spn (MOF-808). ${ }^{14-17} \mathrm{Zr}$-MOFs are often prepared employing high boiling hazardous solvents such as $\mathrm{N}, \mathrm{N}$-dimethylformamide (DMF), strong acids and soluble chloride or nitrate metal salts. ${ }^{18} \mathrm{~A}$ remarkable effort has been recently made for ensuring safer and cleaner procedures for the synthesis of MOFs by using different approaches able to

\footnotetext{
aipartimento di Chimica Biologia e Biotecnologia, University of Perugia, Via Elce di Sotto 8, 06123 Perugia, Italy.Email:ferdinando.costantino@unipg.it

b. Energy Safety Research Institute, Swansea University, Fabian Way, Swansea SA1 8EN, United Kingdom. Email: marco.taddei@swansea.ac.uk
}

minimize the use of hazardous reagents and high-boiling solvents and the generation of large amounts of waste byproducts. ${ }^{19}$ Mechanochemistry is a well-established approach for performing clean and fast syntheses of a wide range of compounds, including metal-organic materials, avoiding common solvothermal routes and maximizing the atom economy. ${ }^{20}$ In particular, liquid assisted grinding (LAG) or ionicliquid assisted grinding (ILAG) are efficient procedures that make use of a small amount of solvents and/or metal-oxide precursors to enhance the crystallization kinetics. ${ }^{21-23}$ Mechanochemical routes have recently been developed for the synthesis of many Zr-MOFs. ${ }^{24}$ In particular, the use of templating agents, water-based LAG and extrusion resulted in the synthesis of Zr-MOFs of different topologies with high yield and high purity. ${ }^{25}$ However, in order to attain the desired phase, preformed $\mathrm{Zr}_{6} \mathrm{O}_{6}(\mathrm{OH})_{4}{ }^{12+}$ clusters already assembled with monocarboxylic ligands, such as acetate or methacrylate, are normally used. ${ }^{25,26}$ These clusters are often prepared using wet chemistry routes, adding a preliminary synthetic step to the procedure. Huang et al. ${ }^{24}$ recently reported the ultrarapid (3 $\mathrm{min}$ ) water-based LAG synthesis of nanocrystalline perfluorinated UiO-66 starting from a preformed methacrylate cluster and tetrafluoroterephthalic acid $\left(\mathrm{F}_{4}-\mathrm{BDC}\right)$. The authors found that other linkers, such as terephthalic acid (BDC), 2aminoterephthalic acid ( $\left.\mathrm{NH}_{2}-\mathrm{BDC}\right)$ and 2-bromoterephthalic acid $(\mathrm{Br}-\mathrm{BDC})$ failed to afford a crystalline product, attributing the higher reactivity of $\mathrm{F}_{4}-\mathrm{BDC}$ to its higher acidity, which enhances its solubility in water. Indeed, $\mathrm{F}_{4}-\mathrm{BDC}$ has recently been employed for the synthesis of UiO-66 type MOFs in water, even at room temperature. ${ }^{27-30}$ Notably, Ye et al. ${ }^{31}$ recently reported on a simple method to produce UiO-66 in high yield by grinding $\mathrm{ZrOCl}_{2} \cdot 8 \mathrm{H}_{2} \mathrm{O}$ and $\mathrm{BDC}$ and subsequently heating the resulting mixture at $130{ }^{\circ} \mathrm{C}$ for 12 hours. Attempts using $\mathrm{ZrCl}_{4}$ and $\mathrm{Zr}\left(\mathrm{NO}_{3}\right)_{4} \cdot 5 \mathrm{H}_{2} \mathrm{O}$ as precursors failed to afford a crystalline product. Inspired by these works, we set out to combine these two approaches to investigate the synthesis of a range of functionalised UiO-66 analogues starting from several commercially available $\mathrm{Zr}$ precursors, namely, $\mathrm{Zr}\left(\mathrm{NO}_{3}\right)_{4} \cdot 5 \mathrm{H}_{2} \mathrm{O}$, $\mathrm{ZrOCl}_{2} \cdot 8 \mathrm{H}_{2} \mathrm{O}, \mathrm{ZrO}\left(\mathrm{NO}_{3}\right)_{2} \cdot 4 \mathrm{H}_{2} \mathrm{O}$ and $\mathrm{ZrCl}_{4}$, and a range of linkers 
with variable acidity, namely, $\mathrm{F}_{4}-\mathrm{BDC}, \mathrm{Br}-\mathrm{BDC}, \mathrm{NH}_{2}-\mathrm{BDC}$, 2nitroterephthalic acid ( $\left.\mathrm{NO}_{2}-\mathrm{BDC}\right)$ and 2,5-pyridine dicarboxylic acid (PyDC) (Figure 1).<smiles>O=C(O[Ga])c1c(F)c(F)c(C(=O)O[Ga])c(F)c1F</smiles>
F4-BDC<smiles>[Z10]C(=O)c1ccc(C(=O)[18OH])c(Br)c1</smiles>

$\mathrm{Br}-\mathrm{BDC}$<smiles>O=C(O[GaH])c1ccc(C(=O)O[Ga])c([N+](=O)[O-])c1</smiles>
$\mathrm{NO}_{2}-\mathrm{BDC}$

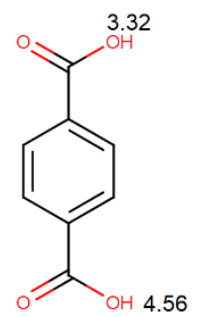

$\mathrm{BDC}$

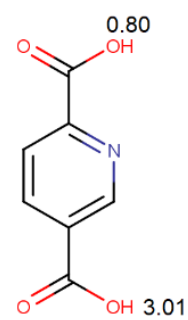

PyDC

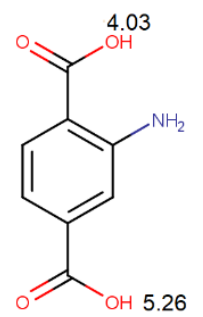

$\mathrm{NH}_{2}-\mathrm{BDC}$
Figure 1. Molecular structure of the linkers used in this work. pKa values are also included next to the corresponding carboxylic groups. The values were calculated using the online tool Chemicalize (chemicalize.com).

We started our investigation by screening the different $\mathrm{Zr}$ precursors in combination with $\mathrm{F}_{4}-\mathrm{BDC}$, which was demonstrated by Huang et al. ${ }^{27}$ to be very prone to quick form a UiO-66 phase when milled with preformed hexanuclear $\mathrm{Zr}$ clusters. Initial attempts consisted in simply grinding equimolar amounts of the $\mathrm{Zr}$ precursor and $\mathrm{F}_{4}-\mathrm{BDC}$ ( $1 \mathrm{mmol}$ each) in a mortar in the presence of $1 \mathrm{~mL}$ of acetic acid ( $\mathrm{AcOH}, 99.7 \%, 17.5$ $\mathrm{mmol}$ ) for five minutes. The resulting slurry was then transferred to a closed container and incubated at RT for 24 hours. The mixture was then washed with water to remove the unreacted $\mathrm{Zr}$ salts and linker and centrifuged in order to recover the solid. Using these amounts of reagents, a concentration of $1 \mathrm{M}$ of both salt and linker was obtained, which is 10 to 40 times higher than that normally used for DMF- or water-based syntheses of UiO-66 type MOFs. 25,29,32-34 We avoided the direct addition of water as solvent since the amount needed to form the clusters (1.33 equivalents) was already present in the hydrated $\mathrm{Zr}$ salts used as metal source. Quite surprisingly, we obtained phase-pure and crystalline UiO-66 from $\mathrm{Zr}\left(\mathrm{NO}_{3}\right)_{4} \cdot 5 \mathrm{H}_{2} \mathrm{O}, \mathrm{ZrOCl}_{2} \cdot 8 \mathrm{H}_{2} \mathrm{O}$ and $\mathrm{ZrCl}_{4}$ (Figure 2a). In the case of $\mathrm{ZrO}\left(\mathrm{NO}_{3}\right)_{2} \cdot 4 \mathrm{H}_{2} \mathrm{O}$, the mixture had to be heated to $120^{\circ} \mathrm{C}$ in order to obtain a crystalline product (Figure $1 \mathrm{~S}$ ). The products obtained from $\mathrm{Zr}\left(\mathrm{NO}_{3}\right)_{4} \cdot 5 \mathrm{H}_{2} \mathrm{O}$ and $\mathrm{ZrOCl}_{2} \cdot 8 \mathrm{H}_{2} \mathrm{O}$ displayed broad reflections around $4-5^{\circ} 2 \theta$, which could be associated with the presence of defects. No residual reflections of the linker were present in the products (Figure 2S). SEM micrographs show that MOF crystallites with no defined morphology and size in the nanometric range (below $100 \mathrm{~nm}$ ) were formed (Figure 3S). Although $\mathrm{ZrCl}_{4}$ is an anhydrous salt, its use was likely successful because it is highly sensitive to moisture and, during grinding, it could have absorbed water from atmosphere. The $\mathrm{N}_{2}$ adsorption-desorption isotherms at $77 \mathrm{~K}$ obtained with these samples are reported in Figure $2 \mathrm{~b}$ and they can be classified as type I isotherms, which are typical of microporous materials. The specific surface area and micropore volumes were calculated from the Brunauer-Emmett-Teller (BET) and t-plot analyses of the adsorption data, respectively, and are reported in Table 1. The highest BET surface area of $882 \mathrm{~m}^{2} \mathrm{~g}^{-1}$ was recorded for the sample obtained from $\mathrm{Zr}\left(\mathrm{NO}_{3}\right)_{4} \cdot 5 \mathrm{H}_{2} \mathrm{O}$. This value is higher than that previously reported for perfluorinated UiO-66 synthesized in water. ${ }^{25,28} \mathrm{ZrCl}_{4}$ produces by far the least porous product, which could be explained by the formation of amorphous, non-porous impurities due to the lower amount of water present in this precursor, compared to the other ones.

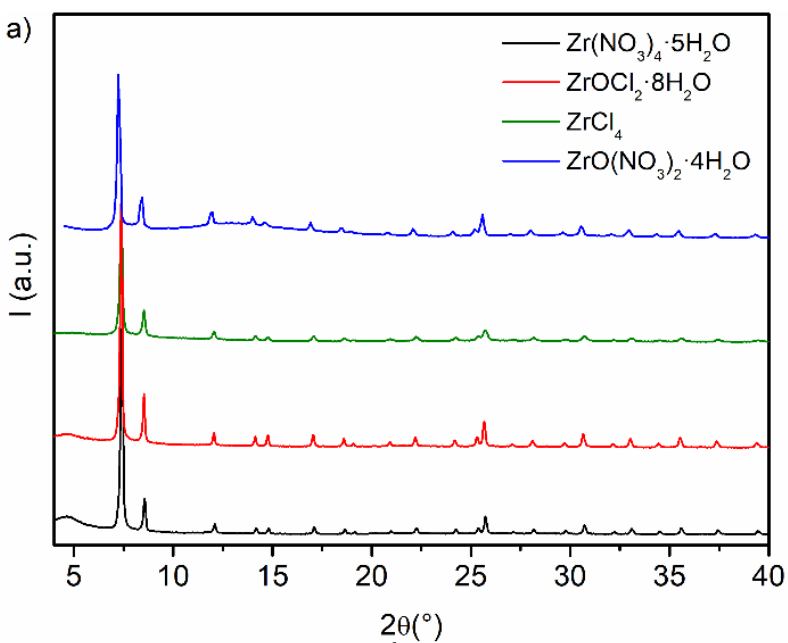

b)

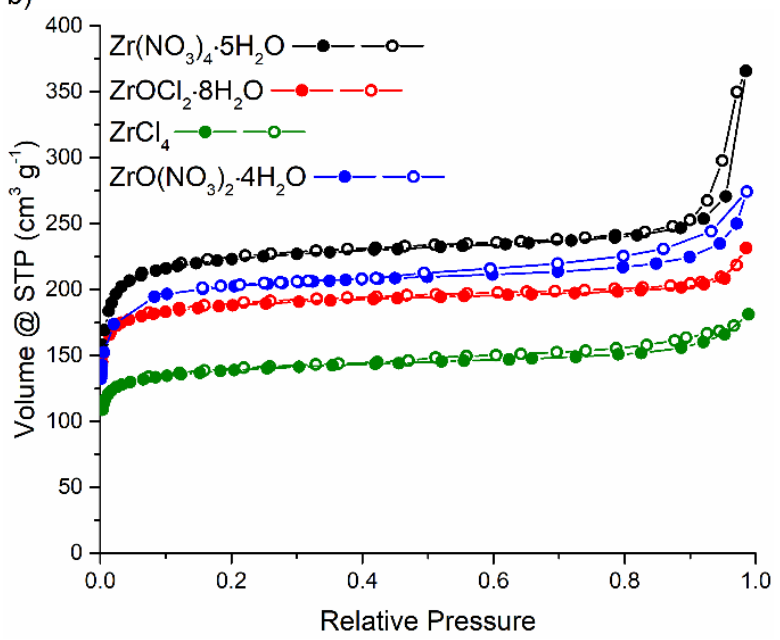

Figure 2. PXRD patterns (a) and $\mathrm{N}_{2}$ adsorption isotherms at $77 \mathrm{~K}(\mathrm{~b})$ of the products obtained from the reaction of $\mathrm{F} 4-\mathrm{BDC}$ with $\mathrm{Zr}\left(\mathrm{NO}_{3}\right)_{4} \cdot 5 \mathrm{H}_{2} \mathrm{O}$ (black), $\mathrm{ZrOCl}_{2} \cdot 8 \mathrm{H}_{2} \mathrm{O}$ (red) and $\mathrm{ZrCl}_{4}$ (olive) at RT and with $\mathrm{ZrO}\left(\mathrm{NO}_{3}\right)_{2} \cdot 4 \mathrm{H}_{2} \mathrm{O}$ at $120^{\circ} \mathrm{C}$ (blue).

NMR analysis of the solids digested in $1 \mathrm{M} \mathrm{NaOH}$ in $\mathrm{D}_{2} \mathrm{O}$ showed that a little $\mathrm{AcOH}$ was retained within all the MOFs except the one prepared with $\mathrm{ZrOCl}_{2} \cdot 8 \mathrm{H}_{2} \mathrm{O}$, suggesting the presence of some defects (Figures 4S-7S). Thermogravimetric analysis (TGA) shows that all products start decomposing at a similar temperature of $300{ }^{\circ} \mathrm{C}$, consistent with that observed in previous literature reports (Figure $8 \mathrm{~S}$ ). ${ }^{1,28}$ The synthesis was also tried with smaller amount of $\mathrm{AcOH}(0.1 \mathrm{~mL})$, using 
$\mathrm{Zr}\left(\mathrm{NO}_{3}\right)_{4} \cdot 5 \mathrm{H}_{2} \mathrm{O}$ as metal precursor, obtaining products with lower crystallinity (Figure 9S), suggesting that a high $\mathrm{AcOH} / \mathrm{Zr}$ ratio is crucial to aid formation of metal clusters and induce formation of a well crystallised MOF. These results suggest that $\mathrm{Zr}\left(\mathrm{NO}_{3}\right)_{4} \cdot 5 \mathrm{H}_{2} \mathrm{O}$ is the most suitable precursor to obtain UiO-66 with high crystallinity and porosity in mild conditions.

Table 1. BET surface area and micropore volume values for perfluorinated UiO-66 samples synthesised starting from different $\mathrm{Zr}$ precursors.

\begin{tabular}{cccc}
\hline Precursor & $\begin{array}{c}\text { Incubation } \\
\text { temperature }\end{array}$ & $\begin{array}{c}\text { BET surface } \\
\text { area } \\
\left(\mathbf{m}^{2} \mathbf{~ g}^{-1}\right)\end{array}$ & $\begin{array}{c}\text { Micropore } \\
\text { Volume } \\
\left(\mathbf{c m}^{3} \mathbf{~ g}^{-1}\right)\end{array}$ \\
\hline $\mathrm{Zr}\left(\mathrm{NO}_{3}\right)_{4} \cdot 5 \mathrm{H}_{2} \mathrm{O}$ & $\mathrm{RT}$ & 882 & 0.31 \\
$\mathrm{ZrOCl}$ & \\
$\mathrm{ZrCl}_{4} \cdot 8 \mathrm{H}_{2} \mathrm{O}$ & $\mathrm{RT}$ & 750 & 0.27 \\
$\mathrm{ZrO}\left(\mathrm{NO}_{3}\right)_{2} \cdot 4 \mathrm{H}_{2} \mathrm{O}$ & $\mathrm{RT}$ & 540 & 0.19 \\
\hline
\end{tabular}

We then moved on to screen linkers bearing different functional groups. The same procedure described above was employed, using $\mathrm{Zr}\left(\mathrm{NO}_{3}\right)_{4} \cdot 5 \mathrm{H}_{2} \mathrm{O}$ as the metal precursor and simply replacing $\mathrm{F}_{4}-\mathrm{BDC}$ with either $\mathrm{Br}-\mathrm{BDC}, \mathrm{NO}_{2}-\mathrm{BDC}, \mathrm{PyDC}, \mathrm{NH}_{2}-\mathrm{BDC}$ or $\mathrm{BDC}$ (Figure 1). Incubation of the mixture at RT only afforded a reasonably crystalline and porous UiO-66 phase for $\mathrm{NO}_{2}-\mathrm{BDC}$ (BET s.a. $=842 \mathrm{~m}^{2} \mathrm{~g}^{-1}$, micropore volume $=0.29 \mathrm{~cm}^{3} \mathrm{~g}^{-1}$, consistent with previous literature reports) 33,34 (Figure 3, Table 2). In an attempt to improve the quality of this product, we heated the mixture to $120^{\circ} \mathrm{C}$, but, quite surprisingly, this led to a less crystalline and less porous MOF (micropore volume $=0.23$ $\mathrm{cm}^{3} \mathrm{~g}^{-1}$ ) (Figures 10S-11S). NMR analysis shows that the products contain similar amounts of $\mathrm{AcOH}$ (Figures 12S-13S). Comparison of the TGA curves shows that they start decomposing at the same temperature (about $350{ }^{\circ} \mathrm{C}$ ), but the one obtained at RT loses considerably less weight (Figure 14S). In the case of $\mathrm{Br}-\mathrm{BDC}$, the phase formed at RT did resemble UiO66 , but its crystallinity was clearly unsatisfactorily (Figure 15S). Heating to $120^{\circ} \mathrm{C}$ was necessary to obtain a crystalline product, whose surface area (BET s.a. $=526 \mathrm{~m}^{2} \mathrm{~g}^{-1}$ ) was still lower than that usually reported in the literature, ${ }^{32,35,36}$ comprised between 718 and $851 \mathrm{~m}^{2} \mathrm{~g}^{-1}$ (Figure $3 \mathrm{~b}$ )). NMR analysis showed that the sample contained the highest amount of $\mathrm{AcOH}$ among all the MOFs here reported (Figure 16S). This suggests the potential presence of amorphous, non-porous impurities. In the case of $\mathrm{PyDC}, \mathrm{ACOH}$ proved not to be an effective modulator in any condition, therefore addition of $1 \mathrm{~mL}$ of concentrated $\mathrm{HNO}_{3}$ (65\%) was attempted, drawing inspiration from a literature synthetic protocol, where concentrated $\mathrm{HCl}$ was employed to prevent the formation of an amorphous phase. ${ }^{37}$ We chose to use $\mathrm{HNO}_{3}$ in order to avoid the introduction of an additional species, i.e. chloride, in the reaction mixture. While incubation at RT did not succeed in affording a crystalline product (Figure $17 \mathrm{~S})$, heating to $120^{\circ} \mathrm{C}$ did produce a highly crystalline solid, with BET s.a. of $1108 \mathrm{~m}^{2} \mathrm{~g}^{-1}$ and micropore volume of $0.41 \mathrm{~cm}^{3}$ $\mathrm{g}^{-1}$ (Figure 3, Table 2). This product is significantly less porous than previously reported analogues 37,38 with BET s.a. ranging between 1380 and $1797 \mathrm{~m}^{2} \mathrm{~g}^{-1}$. However, these literature samples contained large amounts of defects, which contributed to inflate their porosity. Given that PyDC and BDC have basically the same molecular weight and steric demand, a BET s.a. value of $1108 \mathrm{~m}^{2} \mathrm{~g}^{-1}$ is consistent with the values usually reported for defect-free and non-functionalised UiO-66. ${ }^{39}$ However, the wt\% of PyDC in the MOF derived from NMR analyisis is lower than expected for a non-defective sample (Figure 18S). This could be due to the presence of either amorphous, non-porous impurities or some $\mathrm{NO}_{3}{ }^{-}$as counterion of the protonated pyridine rings. SEM micrographs show that MOF crystallites with no defined morphology and size in the nanometric range (below $100 \mathrm{~nm}$ ) were formed with $\mathrm{NO}_{2}-\mathrm{BDC}$ and $\mathrm{Br}-\mathrm{BDC}$, whereas PyDC gave octahedral crystallites (Figure 3S). No residual reflections of the linker were present in any of the products (Figure $2 \mathrm{~S}$ ).
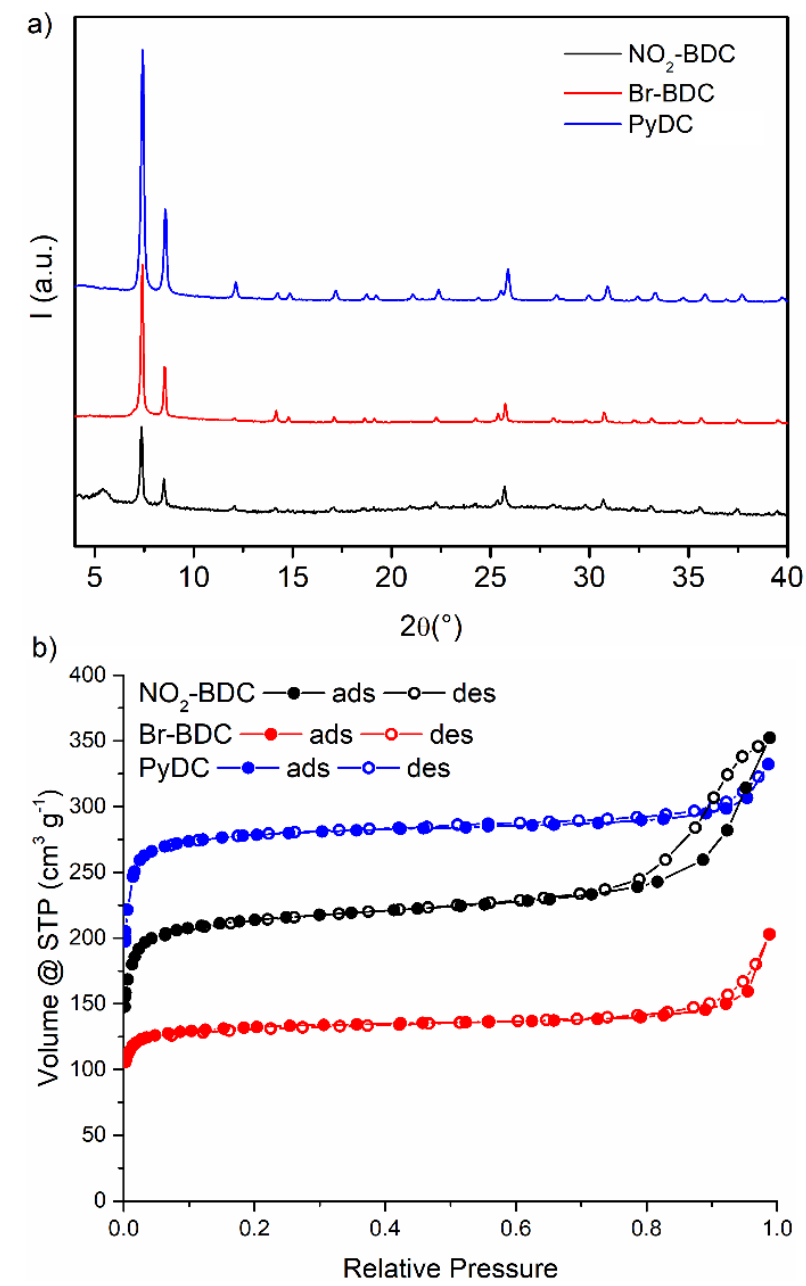

Figure 3. PXRD patterns (a) and $\mathrm{N}_{2}$ adsorption isotherms at $77 \mathrm{~K}(\mathrm{~b})$ of the products obtained from the reaction of $\mathrm{Zr}\left(\mathrm{NO}_{3}\right)_{4} \cdot 5 \mathrm{H}_{2} \mathrm{O}$ with $\mathrm{NO}_{2}-\mathrm{BDC}$ at $\mathrm{RT}$ (black)andwith $\mathrm{Br}-\mathrm{BDC}$ (red) and PyDC (blue) at $120^{\circ} \mathrm{C}$.

Every attempt at using $\mathrm{NH}_{2}-\mathrm{BDC}$ and $\mathrm{BDC}$ as linkers invariably ended with an amorphous product. This is probably because these ligands are not acidic enough and therefore not able to effectively deprotonate in reaction conditions. As shown in Figure $1, \mathrm{pKa}_{1}$ values of $\mathrm{BDC}$ and $\mathrm{NH}_{2}-\mathrm{BDC}$ are 3.32 and 4.03, 
respectively, about one order of magnitude lower than that of $\mathrm{Br}-\mathrm{BDC}$ (2.72) and more than two orders of magnitude lower than those of $\mathrm{F}_{4}-\mathrm{BDC}(1.18), \mathrm{NO}_{2}-\mathrm{BDC}(0.72)$, and PyDC (0.80). Since solubility in water is highly dependent on the acidity of the carboxylic linker, which is in turn related to the presence of electron-withdrawing substituents on the aromatic ring, we speculate that less acidic linkers, such as $\mathrm{BDC}$ and $\mathrm{NH}_{2}-\mathrm{BDC}$, fail to dissolve in the small amount of water contained in the $\mathrm{Zr}$ precursor, thus preventing crystallisation of the MOF from occurring. On the other hand, the higher water solubility of $\mathrm{F}_{4^{-}}$ $\mathrm{BDC}, \mathrm{NO}_{2}-\mathrm{BDC}, \mathrm{Br}-\mathrm{BDC}$ and $\mathrm{PyDC}$ allows the rapid reaction with hydrated $\mathrm{Zr}$ salts upon grinding and successive incubation at RT or $120^{\circ} \mathrm{C}$

Table 2. BET surface area and micropore volume values for UiO-66 samples synthesised using different organic linkers.

\begin{tabular}{cccc}
\hline Linker & $\begin{array}{c}\text { Incubation } \\
\text { temperature }\end{array}$ & $\begin{array}{c}\text { BET surface } \\
\text { area } \\
\left(\mathbf{m}^{2} \mathbf{~ g}^{-1}\right)\end{array}$ & $\begin{array}{c}\text { Micropore } \\
\text { Volume } \\
\left(\mathbf{c m}^{3} \mathbf{~ g}^{-1}\right)\end{array}$ \\
\hline $\mathrm{NO}_{2}-\mathrm{BDC}$ & $\mathrm{RT}$ & 842 & 0.29 \\
$\mathrm{Br}-\mathrm{BDC}$ & $120^{\circ} \mathrm{C}$ & 526 & 0.18 \\
$\mathrm{PyDC}$ & $120^{\circ} \mathrm{C}$ & 1108 & 0.41 \\
\hline
\end{tabular}

In order to test the possibility to scale-up the synthetic procedure, a ball mill was used for the mixing stage. The synthesis of UiO-66 using $\mathrm{F}_{4}-\mathrm{BDCandZr}\left(\mathrm{NO}_{3}\right)_{4} \cdot 5 \mathrm{H}_{2} \mathrm{O}(4 \mathrm{mmol}$ each) and $4 \mathrm{~mL}$ of $\mathrm{AcOH}$ was initially tried by milling for $1 \mathrm{~h}$ at 30 $\mathrm{Hz}$, observing formation of a UiO-66 phase with low crystallinity and porosity (Figures 19S-20S). In a successive attempt, where the vessel was kept sealed for $24 \mathrm{~h}$ after initial milling, $1.5 \mathrm{~g}$ of a well crystallized compound was obtained, whose crystallinity is comparable to that obtained by hand-grinding the reagents (Figure 19S). This product displays BET s.a. of $888 \mathrm{~m}^{2} \mathrm{~g}^{-1}$ and micropore volume of $0.33 \mathrm{~cm}^{3} \mathrm{~g}^{-1}$, about the same of that measured for the MOF obtained with the small scale synthesis (Figure 20S). The scale of the reaction is limited by the volume $(10 \mathrm{~mL})$ of the vessel available to us, but the success of this fourfold scale up suggests that it could be further increased. This demonstrates that ball milling is effective for scaled-up syntheses because it allows a more efficient mixing of the reagents when they are in large amounts and hand-grinding is not practical. However, it does not appear to have evident benefits in terms of kinetics of crystallization.

\section{Conclusions}

A novel synthetic route for $\mathrm{Zr}$-MOFs with UiO-66 structure is here presented. The synthetic protocol is extremely easy as it does not make use of solvents and preformed $\mathrm{Zr}_{6}$ clusters. The procedure was successfully validated with different $Z r$ salts and dicarboxylic linkers at the laboratory scale. The protocol works best with linkers having high acidity, such as tetrafluoro-, 2nitro- and 2-bromoterephthalic acid and 2,5pyridinedicarboxylic acid. High acidity allows facile deprotonation in the presence of the crystallisation water contained in the metal precursors, thus promoting formation of the $\mathrm{Zr}$ clusters. We also demonstrated that the use of ball mill for the grinding stage permits a four-fold scale up of the synthesis, while affording a product of identical quality.

\section{Acknowledgement}

The authors acknowledge the European Union's Horizon 2020 research and innovation programme under the Marie Skłodowska-Curie grant agreement No 663830 (M.T.), and the Engineering and Physical Sciences Research Council (EPSRC) for funding through the First Grant scheme EP/R01910X/1 (M.T. and M.J.M.). Prof Paul M. Williams (Swansea University) is acknowledged for providing access to the gas sorption analyser.

\section{Conflicts of interest}

There are no conflicts to declare.

\section{Notes and references}

1 H. Reinsch, Eur. J. Inorg. Chem., 2016, 4290-4299.

2 S. Wang and C. Serre, ACS Sustainable Chem. Eng., 2019, 7, 11911-11927.

3 P. A. Julien, C. Mottillo and T. Friščić Green Chem., 2017, 19, 2729-2747.

4 T. D. Bennett and S. Horike, Nat. Rev. Mater., 2018, 3, 431440.

5 K. Adil, Y. Belmabkhout, R. S. Pillai, A. Cadiau, P. M. Bhatt,A. H. Assen, G. Maurin and M. Eddaoudi, Chem. Soc. Rev., 2017, 46, 3402-3430.

6 J. A. Mason, M. Veenstra and J. R. Long, Chem. Sci., 2014, 5, 32-51.

7 Z. Chen, K. Adil, L. J. Weselinski, Y. Belmabkhout and M.Eddaoudi, J. Mater. Chem. A, 2015, 3, 6276-6281.

8 J. E. Mondloch, M. J. Katz, W. C. Isley lii, P. Ghosh, P. Liao, W. Bury, G. W. Wagner, M. G. Hall, J. B. DeCoste, G. W.Peterson, R. Q. Snurr, C. J. Cramer, J. T. Hupp and O. K.Farha, Nat. Mater., 2015, 14, 512-516.

9 D. Yang and B. C. Gates ACS Catalysis, 2019, 9, 1779-1798.

10 A. Cadiau, Y. Belmabkhout, K. Adil, P. M. Bhatt, R. S. Pillai, A. Shkurenko, C. Martineau-Corcos, G. Maurin and M. Eddaoudi, Science, 2017, 356, 731-735.

11 Z. Chen, P. Li, X. Zhang, P. Li, M. C. Wasson, T. Islamoglu, J. F. Stoddart and O. K. Farha, J. Am. Chem. Soc., 2019, 141, 29002905.

12 J. Escorihuela, R. Narducci, F. Costantino and F. Companon, Adv. Mater. Interfaces, 2019, 6, 1801146

13 M.X Wu and Y. W. Yang, Adv. Mater., 2017, 29, 1606134.

14 J. H.Cavka, S. Jakobsen, U.Olsbye, N. Guillou, C. Lamberti, S. Bordiga and K.P. LillerudJ. Am. Chem. Soc., 2008, 130, 13850-13851.

15 O. K. Farha, A. Ö. Yazaydın, I. Eryazici, C. D. Malliakas, G. H. Brad, M. Kanatzidis, S. T. Nguyen, S. Q Randall and J. T. Hupp, Nature Chem., 2010, 2, 944-948.

16 D. Feng, Z.-Y. Gu, J.-R. Li, H.-L. Jiang, Z. Wei and H.-C. Zhou, Angew.Chem. Int. Ed., 2012, 51, 10307-10310.

17 J.C. Jiang, F. Gándara, Y.B. Zhang, K. Na, O.M. Yaghi and W.G. Klemperer, J. Am. Chem. Soc., 2014, 136, 12844-12847.

18 A. U.Czaja, N. Trukhan and U. Muller, Chem. Soc. Rev., 2009, 38, 1284. 
19 Y. Bai, Y. Dou, L.-H. Xie, W. Rutledge, J.-R. Li and H.-C. Zhou, Chem. Soc. Rev., 2016, 45, 2327-2367.

20 T. Friščić and W. Jones, Cryst. Growth Des., 2009, 9, 1621-1637.

21 Beldon, P. J.; Fábián, L.; Stein, R. S.; Thirumurugan, A.; Cheetham, A. K.; Friščić, T., Angew. Chem. Int. Ed. 2010, 49, 9640-9643.

22 S. L. James, C. J. Adams, C. Bolm, D. Braga, P. Collier, T. Friščić, F. Grepioni, K. D. M. Harris, G. Hyett, W. Jones, A. Krebs, J. Mack, L. Maini, A. G. Orpen, I. P. Parkin, W. C. Shearouse, J. W. Steed and D. C. Waddell, Chem. Soc. Rev., 2012, 41, 413-447.

23 Julien, P. A.; Užarević, K.; Katsenis, A. D.; Kimber, S. A. J.; Wang, T.; Farha, O. K.; Zhang, Y.; Casaban, J.; Germann, L. S.; Etter, M.; et al, J. Am. Chem. Soc., 2016, 138 (9), 2929-2932.

24 Y.-H. Huang, W.-S. Lo, Y.-W. Kuo, W.-J. Chen, C.-H. Lin, F.-K. Shieh, Chem. Commun., 2017, 53, 5818-5821.

25 B. Karadeniz, A. J. Howarth, T. Stolar, T. Islamoglu, I. Dejanović, M. Tireli, M. C. Wasson, S.-Y. Moon, O. K. Farha, T. Friščić and K.Užarević, ACS Sustainable Chem. Eng., 2018, 6, 15841-15849.

26 K. Užarević', T.C. Wang, S.-Y. Moon, A. M. Fidelli, J.T. Hupp, O. K. Farha and T. Friščić, Chem. Commun., 2016, 52, 21332136.

27 H. Reinsch, B. Bueken, F. Vermoortele, I. Stassen, A. Lieb, K.P. Lillerundand D. De Vos, CrystEngComm, 2015, 17, 40704074.

28 Z.Chen, X. Wang, H. Noh, G. Ayoub, G. W. Peterson, C. T. Buru, T. Islamoglu and O. K. Farha, CrystEngComm, 2019, 21, 2409-2415.

29 Z. Hu, A. Gami, Y. Wang and D. Zhao, Adv. Sustainable Syst., 2017, 1, 1700092-1700104.

30 R. D'Amato, A. Donnadio, M. Carta, C. Sangregorio, D. Tiana, R. Vivani, M. Taddei and F. Costantino, ACS Sustainable Chem. Eng., 2019, 7, 394-402.

31 G. Ye, D. Zhang, X. Li, K. Leng, W. Zhang, J. Ma, Y. Sun, W. Xu and S. Ma, ACS Appl. Mater. Interfaces, 2017, 9, 34937 34943.

32 M. Taddei, D. Tiana, N. Casati, J. A. van Bokhoven, B. Smit and M. Ranocchiari, Phys. Chem. Chem. Phys, 2017, 19, 15511559.

33 M. Taddei, R. J. Wakeham, A. Koutsianos, E. Andreoli and A. R. Barron, Angew. Chem. Int. Ed., 2018, 57, 11706-11710.

34 M.J. Katz, Z. J. Brown, Y. J. Colon, P.I W. Siu, K. A. Scheidt, R.Q. Snurr, J. T. Huppand O. K. Farha, Chem. Commun., 2013, 49, 9449-9451.

35 M. Kandiah, M. H. Nilsen, S. Usseglio, S. Jakobsen, U. Olsbye, M. Tilset, C. Larabi, E.A. Quadrelli, F. Bonino and K.P. Lillerud, Chem. Mater., 2010, 22, 6632-6640.

36 S. J. Garibay and S. M. Cohen, Chem. Commun., 2010, 41, 7700 -7702 .

37 A. A. Barkhordarian and C. J. Kepert, J. Mater. Chem. A, 2017, 5, 5612-5618.

38 S. Waitschat, D. Fröhlich, H. Reinsch, H. Terraschke, K. A. Lomachenko, C. Lamberti, H. Kummer, T. Helling, M. Baumgartner, S. Henninger and N. Stock, Dalton Trans., 2018, 47, 1062-1070.

39 G. C. Shearer, S. Chavan, S. Bordiga, S. SVelle, U. Olsbye and K. P. Lillerund, Chem. Mater., 2016, 28, 3749-3761. 